\title{
Molecular Diversity Studies in Cotton (Gossypium hirsutum L.) using SSR Markers
}

\author{
K. Manonmani ${ }^{1 *}$, L. Mahalingam ${ }^{2}$, D. Malarvizhi ${ }^{1}$, N. Premalatha ${ }^{2}$ and N. Sritharan ${ }^{3}$ \\ ${ }^{1}$ Centre for Plant Breeding and Genetics, Tamil Nadu Agricultural University, \\ Coimbatore - 641 003, Tamil Nadu, India \\ ${ }^{2}$ Department of Cotton, Centre for Plant Breeding and Genetics, Tamil Nadu Agricultural \\ University, Coimbatore - 641 003, Tamil Nadu, India \\ ${ }^{3}$ Department of Crop Physiology, Tamil Nadu Agricultural University, \\ Coimbatore - 641 003, Tamil Nadu, India \\ *Corresponding author
}

A B S T R A C T

\section{Keywords}

Molecular diversity, Cotton, SSR markers, UPGMA

Article Info

Accepted:

15 June 2019

Available Online:

10 July 2019
The present investigation was to study the molecular diversity of twelve cotton genotypes, in order to select the suitable divergent parent for heterosis breeding. Totally, 55 primers were used to diversify these genotypes and 40 pairs showed clear, scorable and unambiguous bands. Out of 40, 25 primer pairs $(62.55 \%)$ were found to be polymorphic and 15 found to be monomorphic. The average number of alleles per locus was 1.8. The similarity coefficient ranged from 0.56 to 1.00 with high dissimilarity coefficient of 0.44 for the genotypes TCH 1777 with MCU 13 and TSH 0499 with SVPR 4. A high similarity coefficient of 0.92 was observed among the parents BGDS 1063 with ARBC 19 and TSH 0499 with TSH 1819. The results of cluster analysis grouped twelve genotypes into seven clusters. The largest cluster was cluster A, which had four genotypes and cluster B had two genotypes. The cluster C, D, E, F and G had one genotype type each. Hence, selecting the genotypes for hybridization from different and distant clusters will paves the way to create variability and could be utilized in varietal or hybrid development programme.

\section{Introduction}

India occupies unique position in the global cotton scenario due to several distinct features. India has the largest cotton growing area, possibly the only cotton growing country to grow hybrid cotton involving different species of cotton. It is the native home of old world cultivated cotton and wide diversity in agroclimatic conditions. Cotton has 9 different genomes, 46 wild, 4 cultivated species and probably enriched with sufficient variability. Due to utilization of narrow genetic material in hybridization, cotton yield and quality declined. Thus, evaluation of genetic diversity related to these characters is important for 
sustainable production of cotton as well as cotton breeding. The Assessment of genetic variation among genotypes may help to identify genetically diverse parental lines to exploit heterosis. Although agronomical characterization provides useful information to users, these characteristics are normally subjected to environmental influences and must be assessed during a fixed vegetative phase of the crop. In case of molecular markers, it reveals differences of natural sites at the DNA level. These variations are not seen in phenotype and each might be a single nucleotide differences in a gene or a piece of repetitive DNA. Genetic diversity analysis using molecular markers have been superior over conventional breeding (Melchinger et al., 1991).

Simple Sequence Repeat has become one of the most powerful genetic markers in biology with potential applications for plant breeding programmes (Gupta and Varshney, 2000). SSR markers are abundant among the genomes and show high level of polymorphisms (Powell et al., 1996). The present investigation was to study the molecular diversity of twelve cotton genotypes using SSR markers, in order to select the suitable divergent parent for heterosis breeding.

\section{Materials and Methods}

\section{Genotypes}

A total of twelve cotton genotypes were assessed for polymorphism using SSR markers for studying the extent of genetic diversity among parents. The details of the genotypes were presented in Table 1. Genomic DNA was isolated from the cotton leaves by the procedure suggested by Zhang and Stewart (2000) and the quantity and quality of the DNA was checked for polymerase chain reaction (PCR).

\section{SSR markers}

A total of 55 SSR primer pairs were used to assess the extent of genetic diversity. Among them, 40 showed distinct clear band and the list of primers along with its annealing temperature were furnished in Table 2.

\section{Band scoring}

Data were scored on the basis of the presence or absence of the bands obtained. If a band was present in a genotype, it was designated as ' 1 ' and if absent; it was designated as ' 0 '. The data were maintained in the spread sheet format for further analysis. The data were entered in to binary matrix and subsequently analyzed by using NTSYS-pc version 2.02.

\section{Data Analysis}

The data were subjected to statistical analysis for the calculation of Jaccard's similarity coefficient (Jaccard, 1908). The resultant similarity matrix was entered into SAHN (sequential, agglomerative, hierarchical, and nested clustering method) clustering program, a tree matrix was generated and cluster analysis by UPGMA (unweighted pair-group method with arithmetic averages) using NTSYS-pc version 2.02 based software.

\section{Results and Discussion}

\section{Molecular marker based genetic diversity analysis}

In SSR analysis with 40 microsatellite markers, 25 primer pairs $(62.55 \%)$ showed polymorphism and the rest showed monomorphism among the parents. A total of 47 alleles were produced by 25 primers. The number of alleles revealed by each marker ranged from 2 to 3 . The average number of alleles per locus was found to be 1.8. 2-5 primer alleles with an average of 2.8 per locus 
were recorded by Bertini et al., (2006), Abdellatif et al., (2012) and Mishra et al., (2013). A maximum of three alleles was recorded by JESPR 292, while six markers viz., BNL 1161, HAU 940, NAU 797, TMB 2295, Gh 129 and MUSB 1316.

\section{Similarity coefficient}

The similarity index (SI) values were computed as the ratio of number of similar bands to the total number of bands in pair wise comparison of the genotypes. Genetic similarity co-efficient was estimated for each pair of 12 parents using the binary data from the polymorphic primers.

The similarity coefficient ranged from 0.56 to 1.00 with high dissimilarity coefficient of 0.44 for the genotypes TCH 1777 with MCU 13 and TSH 0499 with SVPR 4. The similarity coefficient of 0.38-0.98 was observed by Rana and Bhat (2005), 9.68-53.29 similarity detected by Patil et al., (2007) and 0.49-1.00 observed by Thiyagu et al., (2011). The similarity co-efficient of the 12 parents was presented in Table 3. ARBC 19 with BGDS 1063 and TSH 0499 with TCH 1819 recorded higher similarity index of 0.92 . It was followed by five genotype combination viz., BGDS 1063 with TSH 0499, ARBC 19 with TSH 0499, MCU 13 with ARBC 19, SVPR 4 with ARBC 19 and Surabhi with ARBC 19, which recorded second highest similarity coefficient of 0.88 .

TSH 0499 had lesser similarity index $(0.56)$ with TCH 1777. Hybridization between these genotypes will provide sufficient variability. But, the genotype TSH 0499 had higher similarity index of 0.92 with TCH 1819 . These results are in accordance with the findings of Ehsan et al., (2013) and Bilwal et al., (2017). Hybridization between closer genotypes should not be advisable for securing greater variability.

Table.1 List of lines, testers and check used in the present investigation

\begin{tabular}{|c|l|l|l|}
\hline S. No & \multicolumn{1}{|c|}{ Genotype } & \multicolumn{1}{|c|}{ Source } & \multicolumn{1}{|c|}{ Special feature } \\
\hline 1. & TSH 0499 & CRS, Srivilliputtur, Tamil Nadu & High yield with big boll size \\
\hline 2. & TSH 04/115 & CRS, Srivilliputtur, Tamil Nadu & High yielding \\
\hline 3. & BGDS 1063 & UAS, Bheemarayangudi, Karnataka & High yielding \\
\hline 4. & ARBC 19 & UAS, Dharwad, Karnataka & Compact, high yielding \\
\hline 5. & MCU 7 & $\begin{array}{l}\text { Department of Cotton, Tamil Nadu } \\
\text { Agricultural University, Coimbatore }\end{array}$ & Early duration \\
\hline 6. & MCU 13 & $\begin{array}{l}\text { Department of Cotton, Tamil Nadu } \\
\text { Agricultural University, Coimbatore }\end{array}$ & High yielding \\
\hline 7. & CO 14 & $\begin{array}{l}\text { Department of Cotton, Tamil Nadu } \\
\text { Agricultural University, Coimbatore }\end{array}$ & $\begin{array}{l}\text { Extra long staple, Moderately Resistant } \\
\text { to Jassid }\end{array}$ \\
\hline 8. & SVPR 4 & CRS, Srivilliputtur, Tamil Nadu & Good fibre strength \\
\hline 9. & KC 3 & $\begin{array}{l}\text { ARS, Kovilpatti, Tamil Nadu } \\
\text { CICR, Coimbatore, Tamil Nadu }\end{array}$ & $\begin{array}{l}\text { Resistant to leaf hopper } \\
\text { Verticillium } \text { wilt Resistant }\end{array}$ \\
\hline 10. & Surabhi & Department of Cotton, Tamil Nadu & High yielding \\
\hline 11. & TCH 1777 & $\begin{array}{l}\text { Agricultural University, Coimbatore } \\
\text { Department of Cotton, Tamil Nadu } \\
\text { Agricultural University, Coimbatore }\end{array}$ & $\begin{array}{l}\text { Compact type, suitable for High density } \\
\text { planting system, Early duration }\end{array}$ \\
\hline 12. & TCH 1819 & & \\
\hline
\end{tabular}


Table.2 Details of simple sequence repeat (SSR) primer used in the study

\begin{tabular}{|c|c|c|c|c|c|c|c|c|}
\hline $\begin{array}{l}\text { S. } \\
\text { No }\end{array}$ & $\begin{array}{c}\text { Primer } \\
\text { name }\end{array}$ & $\begin{array}{c}\text { Annealing } \\
\text { Temp. } \\
\left({ }^{\circ} \mathrm{C}\right)\end{array}$ & $\begin{array}{l}\text { S. } \\
\text { No }\end{array}$ & $\begin{array}{c}\text { Primer } \\
\text { name }\end{array}$ & $\begin{array}{c}\text { Annealing } \\
\text { Temp. } \\
\left({ }^{\circ} \mathrm{C}\right)\end{array}$ & $\begin{array}{l}\text { S. } \\
\text { No }\end{array}$ & $\begin{array}{c}\text { Primer } \\
\text { name }\end{array}$ & $\begin{array}{c}\text { Annealing } \\
\text { Temp. } \\
\left({ }^{\circ} \mathrm{C}\right)\end{array}$ \\
\hline 1. & BNL 1161 & 46.75 & 15. & Gh 610 & 50 & 29. & TMB 2295 & 55 \\
\hline 2. & BNL 1034 & 55 & 16. & HAU 585 & 57 & 30. & СM 029 & 50 \\
\hline 3. & BNL 1317 & 55 & 17. & HAU 940 & 57 & 31. & CM 066 & 50 \\
\hline 4. & BNL 2732 & 48.5 & 18. & JESPR 127 & 58.20 & 32. & CIR 295 & 55 \\
\hline 5. & BNL 2921 & 55 & 19. & JESPR 154 & 58 & 33. & CIR 307 & 46 \\
\hline 6. & BNL 3424 & 55 & 20. & JESPR 292 & 58 & 34. & CIR 407 & 51 \\
\hline 7. & BNL 3623 & 46.75 & 21. & MUSB 0078 & 55 & 35. & DPL 0075 & 49 \\
\hline 8. & BNL 3806 & 47.5 & 22. & MUSB 1316 & 50 & 36. & DPL 0080 & 49 \\
\hline 9. & BNL 4030 & 54.4 & 23. & NAU 0797 & 46.75 & 37. & DPL 0112 & 49 \\
\hline 10. & BNL 4108 & 54.3 & 24. & NAU 0923 & 50.3 & 38. & DPL 0135 & 49 \\
\hline 11. & BNL 1227 & 48.75 & 25. & NAU 1037 & 57 & 39. & DPL 0153 & 49 \\
\hline 12. & Gh 129 & 55 & 26. & NAU 1200 & 49.35 & 40. & DPL 0163 & 50 \\
\hline 13. & Gh 132 & 55 & 27. & NAU 1233 & 57 & & & \\
\hline 14. & Gh 609 & 50 & 28. & TMB 471 & 55 & & & \\
\hline
\end{tabular}

Table.3 Genetic similarity co-efficient values of 12 parental genotypes based on 25 SSR markers (Gossypium hirsutum L.)

\begin{tabular}{|l|l|l|l|l|l|l|l|l|l|l|l|l|}
\hline Genotypes & $\begin{array}{l}\text { TSH } \\
\mathbf{0 4 9 9}\end{array}$ & $\begin{array}{l}\text { TSH } \\
\mathbf{0 4 / 1 1 5}\end{array}$ & $\begin{array}{l}\text { BGDS } \\
\mathbf{1 0 6 3}\end{array}$ & $\begin{array}{l}\text { ARBC } \\
\mathbf{1 9}\end{array}$ & $\begin{array}{l}\text { MCU } \\
\mathbf{1 3}\end{array}$ & $\begin{array}{l}\text { SVPR } \\
\mathbf{4}\end{array}$ & $\begin{array}{l}\text { KC } \\
\mathbf{3}\end{array}$ & $\begin{array}{l}\text { TCH } \\
\mathbf{1 7 7 7}\end{array}$ & Surabhi & $\begin{array}{l}\text { TCH } \\
\mathbf{1 8 1 9}\end{array}$ & $\begin{array}{l}\text { CO } \\
\mathbf{1 4}\end{array}$ & $\begin{array}{l}\text { MCU } \\
\mathbf{7}\end{array}$ \\
\hline TSH 0499 & $\mathbf{1 . 0 0}$ & & & & & & & & & & \\
\hline TSH & 0.76 & $\mathbf{1 . 0 0}$ & & & & & & & & & \\
04/115 & & & & & & & & & & & \\
\hline BGDS & 0.88 & 0.80 & $\mathbf{1 . 0 0}$ & & & & & & & & \\
1063 & & & & & & & & & & & \\
\hline ARBC 19 & 0.88 & 0.80 & 0.92 & $\mathbf{1 . 0 0}$ & & & & & & & & \\
\hline MCU 13 & 0.76 & 0.76 & 0.80 & 0.88 & $\mathbf{1 . 0 0}$ & & & & & & & \\
\hline SVPR 4 & 0.76 & 0.68 & 0.80 & 0.88 & 0.76 & $\mathbf{1 . 0 0}$ & & & & & & \\
\hline KC 3 & 0.68 & 0.68 & 0.72 & 0.72 & 0.60 & 0.68 & $\mathbf{1 . 0 0}$ & & & & & \\
\hline TCH 1777 & 0.56 & 0.64 & 0.60 & 0.60 & 0.56 & 0.56 & 0.72 & $\mathbf{1 . 0 0}$ & & & & \\
\hline Surabhi & 0.76 & 0.76 & 0.80 & 0.88 & 0.76 & 0.76 & 0.76 & 0.64 & $\mathbf{1 . 0 0}$ & & & \\
\hline TCH 1819 & 0.92 & 0.76 & 0.80 & 0.80 & 0.76 & 0.68 & 0.68 & 0.64 & 0.68 & $\mathbf{1 . 0 0}$ & \\
\hline CO 14 & 0.80 & 0.72 & 0.76 & 0.76 & 0.72 & 0.64 & 0.64 & 0.60 & 0.72 & 0.80 & $\mathbf{1 . 0 0}$ & \\
\hline MCU 7 & 0.76 & 0.76 & 0.80 & 0.80 & 0.76 & 0.68 & 0.68 & 0.64 & 0.76 & 0.84 & 0.80 & $\mathbf{1 . 0 0}$ \\
\hline
\end{tabular}


Table.4 Distribution of 12 parental genotypes into 5 clusters based on jaccard's coefficient

\begin{tabular}{|c|c|l|}
\hline Cluster & $\begin{array}{c}\text { No. of } \\
\text { genotype }\end{array}$ & \multicolumn{1}{|c|}{$\begin{array}{c}\text { Name of the } \\
\text { genotype } \\
\text { TSH 0499, CO } \\
\text { 14, BGDS 1063, } \\
\text { ARBC 19 }\end{array}$} \\
\hline A & 4 & $\begin{array}{l}\text { TCH 1819, } \\
\text { MCU 7 }\end{array}$ \\
\hline B & 2 & TSH 04/115 \\
\hline C & 1 & Surabhi \\
\hline D & 1 & SVPR 4 \\
\hline E & 1 & KC 3 \\
\hline F & 1 & TCH 1777 \\
\hline G & 1 &
\end{tabular}

Fig.1 Clustering of 12 cotton genotypes using Jaccard's Coefficient

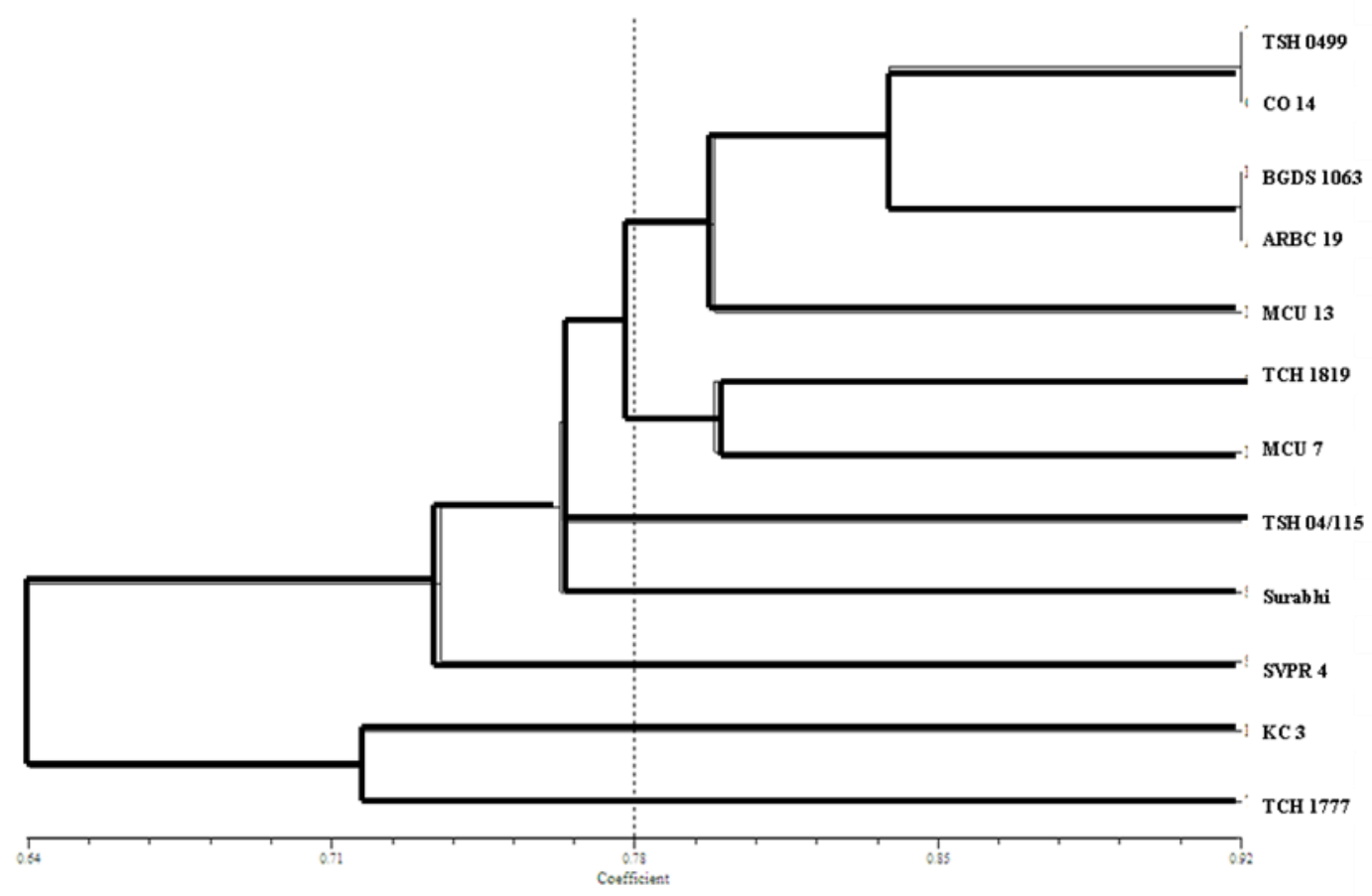

\section{Clustering based on dendrogram}

All the genotypes were scored for presence and absence of bands for the specific alleles of each SSR markers. A dendrogram was made by using the unweighted pair group method of arithmetic average (UPGMA) method by NTSYSpc package version 2.02i.
The dendrogram revealed that all the genotypes were clustered into seven groups (Group A, B, C, D, E, F and G). The number of clusters along with its genotypes was presented in Table 4 and Figure 1. The group 'A' had two subgroups viz., A1 (2 accessions) with TSH 0499 and $\mathrm{CO} 14$ and A2 (2 accessions) with BGDS 1063 and ARBC 19. 
Whereas, the second group (B) clustered two accessions viz., TCH 1819 and MCU 7. The group C, D, E, F and G had one genotype type each viz., TSH 04/115, Surabhi, SVPR 4, KC 3 and TCH 1777 respectively. The group 'A' formed the largest cluster with four accessions. The involvement of genotypes in the different cluster indicated that the varieties with the different genetic composition were falling in one cluster and this can help to conduct a hybridization programme with these genotypes.

Thus, the relatedness of the cultivars studied was efficiently established through the use of SSR markers with some differences in the positioning of some cultivars at various clusters. Dendrogram generated for SSR markers of cotton genotypes reflects the relationships among the most of the $G$. hirsutum L. cultivars depending upon their yield and fibre quality traits which can help conduct hybridization programme with distinct related genotypes.

\section{References}

Abdellatif, K. F., Y. A. Khidr, Y. M. ElMansy, M. M. El-Lawendey and Soliman, Y. A. 2012. Molecular Diversity of Egyptian Cotton (Gossypium barbadense L.) and its Relation to Varietal Development. Journal of Crop Science and Biotechnology, 15 (2): 93 - 99.

Bertini, H.C., I. Schuster, T. Sediyama, E. G. D. Barros and Moreira, M. A. 2006. Characterization and genetic diversity analysis of cotton cultivars using microsatellites. Genetics and Molecular Biology, 29(2): 321-329.

Bilwal, B. B., K. V. Vadodariya, B. K Rajkumar and Lahane, G. R. 2017. Genetic diversity of parents using RAPD, ISSR and SSR molecular markers in upland cotton (Gossypium hirsutum L.). Bull. Environmental Pharmacology Life Science, Vol 6 [8]: 51-57.

Ehsan, B., A. Haque, M. Younas, T. Shaheen, T. Huma, S. Sattar, S. Idrees and Iqbal, Z. 2013. Assessment of Genomic Diversity of Cotton (Gossypium hirsutum L.) Genotypes using Simple Sequence Repeats Markers through Genetic Analysis Software. International Journal of Agricultural Biotechnology, 44: 968-972.

Gupta, P. K. and Varshney, R. K. 2000. The development and use of microsatellite markers for genetics and plant breeding with emphasis on bread wheat. Euphytica, 113: 163-185.

Jaccard, P. 1908. Nouvelles recherché sur la distribution florale. Bull Soc Voud Science Nature, 44: 223-270.

Melchinger, A. E., M. M. Messmer, M. Lee, W. L. Woodman and Lamkey, K. R. 1991. Diversity and relationships among US maize inbreds revealed by restriction fragment length polymorphisms. Crop Science, 31(3): 669-678.

Mishra, K. K., R. S. Fougat and Ballani, A., 2013. Validation of fiber quality linked SSR markers derived from allotetraploid (Gossypium hirsutum) in diploid (Gossypium arboreum). International Journal of Scientific Research Knowledge, 1(9): 349.

Patil, M.D., D. P. Biradar, V. C. Patil, Janagoudar and Nadaf, H. L. 2007. Analysis of genetic diversity of cotton genotypes using RAPD PCR technique. Karnataka Journal of Agricultural Science 20: 215-217.

Powell, W., M. Morgante, Chaz Andre, M. Hanafey, J. Vogel, S. Tingey and Rafalski, A. 1996. The comparison of RFLP, RAPD, AFLP and SSR (microsatellite) markers for germplasm analysis. Molecular Breeding, 2: 225 - 
238.

Rana, M. and Bhat, K. 2005. Assessment of genetic diversity in upland cotton (Gossypium hirsutum L.) breeding lines by using amplified fragment length polymorphism (AFLP) markers and morphological characteristics. Genetics Resources and Crop Evolution, 52: 989997.

Thiyagu. K., N. Manikanda Boopathi, N. Nadarajan, G. Ayyanar, P. Selvakumar,
S. Magadum and Ravikesavan, R. 2011. Sampling and exploitation of genetic variation exist in locally adapted accessions using phenotypic and molecular markers for genetic improvement of cotton. Gene Conservation, 10(40): 129-153.

Zhang, J. and Stewart, J. M. 2000. Economical and rapid method for extracting cotton genomic DNA. Journal of Cotton Science, 4: 193-201.

\section{How to cite this article:}

Manonmani, K., L. Mahalingam, D. Malarvizhi, N. Premalatha and Sritharan, N. 2019. Molecular Diversity Studies in Cotton (Gossypium hirsutum L.) using SSR Markers. Int.J.Curr.Microbiol.App.Sci. 8(07): 1731-1737. doi: https://doi.org/10.20546/ijcmas.2019.807.205 